\title{
Evaluation of seed setting aggregatum onion (Allium cepa var. aggregatum) types under Tamil Nadu conditions
}

\author{
L. Pugalendhi, K. Shoba Thingalmaniyan and M. Velmurugan* \\ Horticultural College and Research Institute, Tamil Nadu Agricultural University \\ Coimbatore - 641 003, India \\ *Corresponding author
}

\begin{tabular}{|l|}
\hline Ke y w o r d s \\
Aggregatum \\
onion, \\
CO 6, \\
Seed, \\
Bulb \\
\hline Article Info \\
\hline Accepted: \\
26 July 2020 \\
Available Online: \\
10 August 2020 \\
\hline
\end{tabular}

\section{A B S T R A C T}

\begin{abstract}
Multiplier onion or Aggregatum onion (Allium cepa var. aggregatum) is one of the important bulbous vegetable cultivated in India. Onion is mainly propagated through bulbs and approximately $1000 \mathrm{~kg}$ of bulb is required for planting in one hectare of area. Huge quantities of onion bulbs are wasted for propagation purpose. By switching over from bulb propagation method to seed, there is a saving of seed bulb to a tune of $1000 \mathrm{~kg} / \mathrm{ha}$. As Aggregatum onion is being cultivated in 30,000 hectares in Tamil Nadu, a saving of 30,000 tonnes bulbs could be obtained. In addition to this, the bulbs must be bolder in size with attractive pink in colour for consumer attraction. Considering the bottlenecks, breeding programme was initiated to develop a seed setting onion type with attractive pink coloured bulbs to meet the demands of domestic and export markets. Based on the results of different phases of evaluation, the overall performance of Aggregatum onion culture Aca 15 is better for the highest mean yield per hectare $(19.10 \mathrm{t})$ when compared $(15.10 \mathrm{t})$ to the check variety Co (On)5 and the per cent increase over $\mathrm{CO}(\mathrm{On}) 5$ (Check) is 20.94 . The organoleptic evaluation was done based on nine point hedonic scale. Based on the organoleptic test, Aca15 recorded maximum score 9 points for colour and flavour and 8 points appearance, texture and taste. However, the check variety $\operatorname{Co}(\mathrm{On}) 5$ recorded 7 points for colour, appearance, texture and taste. The bulbs are bolder in size, attractive pink in colour. Each clump has $5-7$ bulblets. Dry pinkish scale leaves are arranged compactly on the bulbs and bulblets and moderately resistant to purple blotch disease and thrips under field condition. Considering the best performance on bulb yield and quality Aca15 is released as CO 6 during 2020 for the benefit of onion growing regions of Tamil Nadu and other South Indian states.
\end{abstract}

\section{Introduction}

Multiplier onion or Aggregatum onion (Allium cepa var. aggregatum L.) is one of the important bulbous vegetable cultivated in India. Commercially, there are two types of onion are being cultivated in India viz., common onion or big onion (Allium cepa var. сера L.) which is cultivated in larger scale in Maharashtra and Karnataka. The second type of onion is known as aggregatum onion or multiplier onion or small onion (Allium cepa var. aggregatum L.). The aggregatum onion produces many number of smaller sized 
bulbs in cluster form and mostly preferred for their tolerance to pest and diseases and longest storage life than common onion (Brewster, 2008, Anbukkarasi et al., 2012, Anbukkarasi et al., 2013, Pugalendhi et al., 2011a, Pugalendhi et al. 2011b,). Onion possess Quercetin and volatile sulfur compounds which helps in anemia, skin disorders, stomach cancer, eye infection, prevent asthma attack (Ahmed and Bassuorry, 2009 and Lanzotti et al., 2012). The bulb provides $2.0 \mathrm{~g}$ protein, $72 \mathrm{mg}$ calcium and 54 mg phosphorus. It also contains vitamins viz., thiamine, riboflavin and niacin and is used for its medicinal value especially in the case of heart problems (Mettananda and Fordham, 2001 and Shabina et al., 2020).

During 2018-19, onion is cultivated in an area of 21.85 lakh ha with the production of 232.62 lakh tons (National Horticultural Board, 2019). The major Onion producing states are Maharashtra, Madhya Pradesh, Karnataka, Bihar, Rajasthan, Andhra Pradesh, Haryana, West Bengal, Gujarat and Uttar Pradesh in the country. These States account for almost $90 \%$ of the total onion production of the country. The aggregatum onion is one of the most important commercial vegetable crop grown in South India especially in Tamil Nadu and Karnataka. Large scale cultivation of onion is being done through drip fertigation method (Savitha et al. 2008, Savitha et al., 2010 and Savitha et al., 2012). The aggregatum onion accounts for nearly 75 percent of the total onion produced in Tamil Nadu with an average productivity of 12 tonnes per hectare. Onions contain phenolics and flavonoids that have potential antiinflammatory, anticholesterol, anticancer and antioxidant properties. Onion is highly nutritional and it is used for lowering the toxigenicity of oils. It also shows chemopreventive effects and lowers down the risk of effect on gastric cancer.

Onion is mainly propagated through bulbs and approximately $1000 \mathrm{~kg}$ of bulb is required for planting in one hectare of area. Huge quantities of onion bulbs are wasted for propagation purpose. $\mathrm{Co}(\mathrm{On}) 5$ is propagated though seeds (Veeraragavathatham et al., 2006 and Pugalendhi and Thangamani, 2011). By switching over from bulb propagation method to seed, there is a saving of seed bulb to a tune of $1000 \mathrm{~kg} / \mathrm{ha}$. As aggregatum onion is being cultivated in 30,000 hectares in Tamil Nadu, a saving of 30,000 tonnes bulbs could be obtained. In addition to this, the bulbs must be bolder in size with attractive pink in colour for consumer attraction. Considering the bottlenecks, breeding programme was initiated to develop a seed setting onion type with attractive pink coloured bulbs to meet the demands of domestic and export markets.

\section{Materials and Methods}

The breeding of aggregatum onion is carried out at College Orchard, Department of Vegetable Crops, HC\&RI, TNAU, Coimbatore. The survey has been made for the collection of bulbs in different parts of Tamil Nadu and the collected accessions were included in germplasm. The collected accessions were raised individually to study their performance for growth and yield parameters. The selection is done based on high bulb yield and bold sized bulbs and resistant to major pest and diseases. The bulbs of better performing accessions were raised for seed production by caging technique. The seeds obtained from the individual accessions were thrashed and cleaned and used for raising bulb crop in the subsequent season for the selection of identical superior bulbs. The best accession was compared with the check variety $\mathrm{CO}(\mathrm{On}) 5$ for three seasons. Based on their performance Multi Location Trial (MLT), Adoptive Research Trial (ART) and On Farm Trials (OFT) were conducted. The statistical analysis was done by adopting the standard procedures of Panse and Sukhatme 
(1985). The critical difference was worked out at five per cent $(0.05)$ probability. The pooled mean analysis was carried out with
AGRES software package and MS Excel spreadsheet.

\section{Details of Evolution}

Bulb collection through survey in different parts of TamilNadu and included in germplasm

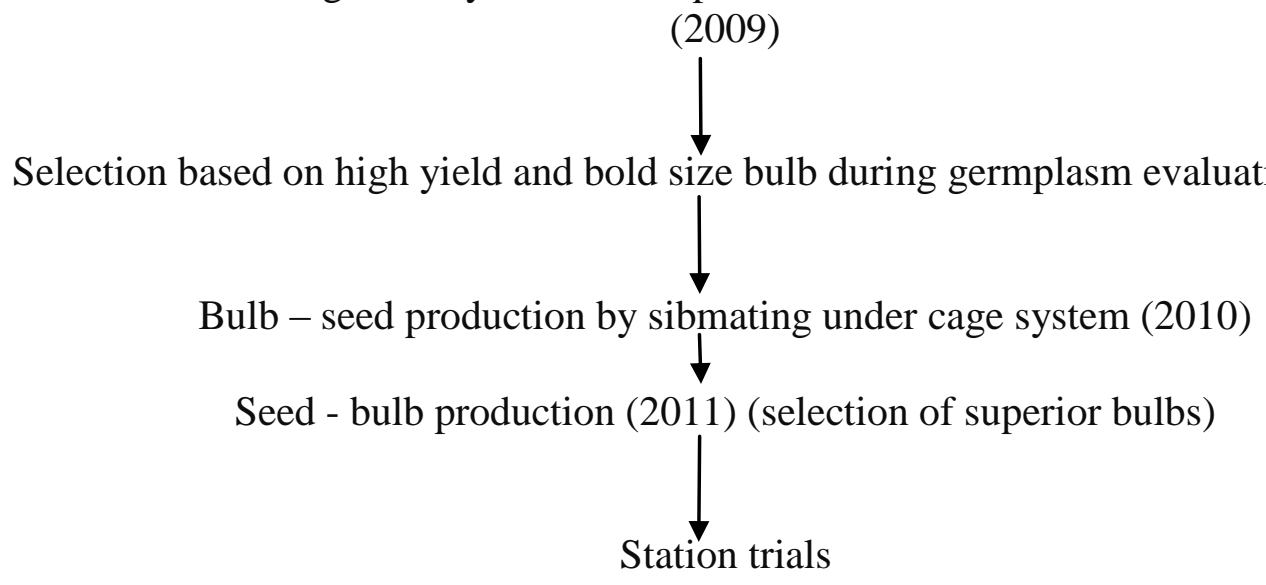

Tested for 3 seasons with check CO (On) 5 during 2012-13, 2013-14 and 2014-15)
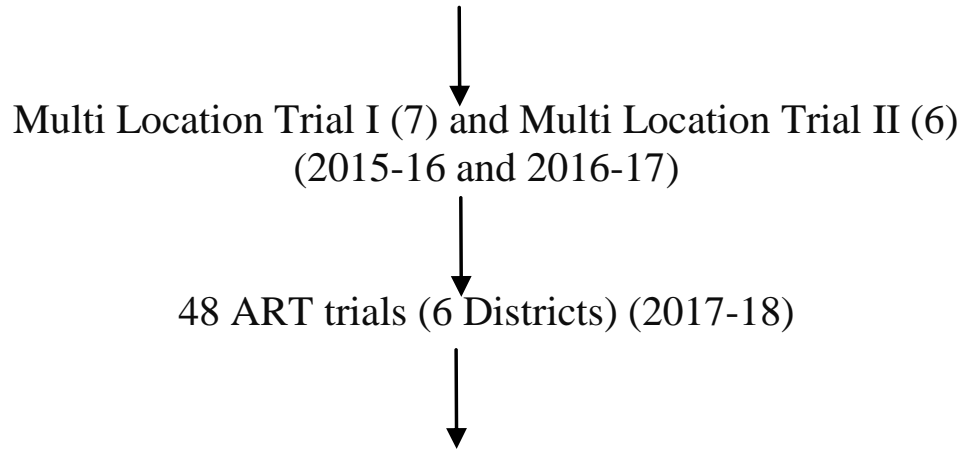

On Farm Trials (5) (2018-19)

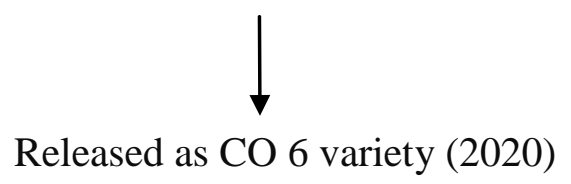

\section{Results and Discussion}

Yield is a complex trait influenced by many factors. In onion, the important yield contributing characters are mean weight of bulblets and bulb diameter. The variations in marketable yield of different varieties could be due to their differences in genetic make-up (Pavlovic et al., 2003) and agro ecological adaptations. In Aca15, the maximum clump weight $(72.30,80.20$ and $89.80 \mathrm{~g})$ was recorded during 2012, 2013 and 2014. Clump weight is the most important component that contributes directly to the yield of aggregatum onion (Shoba Thingalmaniyan et al., 2017). The highest clump weight in this accession may be due to its genetic character and adaptability to agro-climatic conditions by the place of the experiment. Results of the present findings are in accordance with the findings of Boukary et al., (2012) and Moulin et al. (2012). 
The percent purple blotch incidence was less (11.50, 12.70 and 11.90) in Aca15 when compared to Co (On)5 (12,70, 14.00 and 16.30) the check variety respectively during 2012, 2013 and 2014. Similarly, the percent thrips incidence was also lesser $(36.70,39.30$ and 40.20) when compared to Co (On)5 (55.30, 57.70 and 56.50) respectively during 2012, 2013 and 2014 (Table.1). During the process of varietal development, 69 trials were conducted, of which 13 MLT, 48 ART and $50 \mathrm{OFT}$ in onion growing regions. In Aca15, the mean bulb yield is $19.10 \mathrm{t} / \mathrm{ha}$, while $\mathrm{Co}(\mathrm{On}) 5$ (Check variety) recorded $15.10 \mathrm{t} / \mathrm{ha}$ and the per cent increase over $\mathrm{Co}(\mathrm{On}) 5$ is 20.94 .

In MLT-1, the highest bulb yield of 14.70 (t/ha) was recorded in Aca15 than the check variety $\mathrm{Co}(\mathrm{On}) 5(11.20 \mathrm{t} / \mathrm{ha})$. Similarly in MLT-2, the highest bulb yield of 16.87 (t/ha) was recorded in Aca15 than the check variety CO (On)5 (13.13 t/ha) (Table.2). In Adaptive Research Trial, the highest clump weight $(93.22 \mathrm{~g})$, bulb yield per plot $(13.23 \mathrm{~kg} / \mathrm{plot})$ and total bulb yield (19.51 t/ha) was recorded in ACa15. However, the lowest clump weight $(75.25 \mathrm{~g})$, bulb yield per plot $(10.27 \mathrm{~kg} / \mathrm{plot})$ and total bulb yield (15.29 t/ha) was recorded in $\mathrm{Co}(\mathrm{On}) 5$ (Table.3). The overall performance of aggregatum onion culture Aca15 is better for highest mean yield per hectare $(19.10 \mathrm{t})$ when compared $(15.10 \mathrm{t})$ to the check variety $\mathrm{Co}(\mathrm{On}) 5$ and the per cent increase over $\mathrm{CO}(\mathrm{On}) 5$ (Check) is 20.94
(Table.4). Mean performance serves as an important criterion in eliminating the undesirable types in a selection programme. The results of the present investigation revealed that there exists significant difference for growth, yield and quality characters among the different cultivars of multiplier onion (Shoba Thingalmaniyan et al., 2017 and Fathima et al., 2019).

The crop performs differently under varied agro-climatic conditions and various cultivars of the same species grown even in the same environment give different yields as the performance of a cultivar mainly depends on the interaction of genetic makeup and environment (Boukary et al., 2012). Ijoyah et al. (2008) evaluated the yield performance of four onion varieties and found that some other varieties performed better than the commonly grown onion varieties by the farmers. The quality parameters, viz., TSS, ascorbic acid and pyruvic acid contents mainly decide the quality and nutritive value of onion bulbs. Total soluble solids, an important quality criterion for onions, contribute towards flavours (Sharma et al., 1996) and processing quality. With respect to quality parameters, Aca15 recorded the highest TSS content with $15.4^{\circ} \mathrm{B}$ with ascorbic acid content of 10.80 $\mathrm{mg} / \mathrm{g}$ (Table.5). The higher TSS value in these genotypes may be due to its inherent characteristics. Similar results were observed by Pavlovic et al., 2003.

Table.1 Performance of aggregatum onion cultures for bulb yield, purple blotch and thrips incidence

\begin{tabular}{|l|c|c|c|c|c|c|}
\hline \multirow{2}{*}{ Particulars } & \multicolumn{2}{c|}{2012} & \multicolumn{2}{c|}{2013} & \multicolumn{2}{c|}{2014} \\
\cline { 2 - 7 } & Aca15 & $\begin{array}{c}\text { CO(On)5 } \\
\text { (Check) }\end{array}$ & Aca15 & $\begin{array}{c}\text { CO(On)5 } \\
\text { (Check) }\end{array}$ & $\begin{array}{c}\text { Aca15 } \\
\text { CO(On)5 } \\
\text { (Check) }\end{array}$ \\
\hline Average clump weight(g) & 72.30 & 69.20 & 80.20 & 70.00 & 89.80 & 69.70 \\
\hline Total yield (t/ ha) & 20.00 & 15.10 & 20.50 & 15.80 & 22.80 & 17.80 \\
\hline Per cent purple blotch disease incidence & 11.50 & 12.70 & 12.70 & 14.00 & 11.90 & 16.30 \\
\hline Per cent thrips incidence & 36.70 & 55.30 & 39.30 & 57.70 & 40.20 & 56.50 \\
\hline
\end{tabular}


Table.2 Performance of aggregatum onion cultures in Multilocational trials

\begin{tabular}{|c|c|c|c|c|c|c|c|c|c|}
\hline \multirow[t]{3}{*}{ S.No. } & \multirow[t]{3}{*}{ Centres } & \multicolumn{4}{|c|}{ Average clump weight $(\mathrm{g})$} & \multicolumn{4}{|c|}{ Total yield $(\mathrm{t} / \mathrm{ha})$} \\
\hline & & \multicolumn{2}{|c|}{ MLT 1 (2016) } & \multicolumn{2}{|c|}{ MLT 2 (2017) } & \multicolumn{2}{|c|}{ MLT 1 (2016) } & \multicolumn{2}{|c|}{ MLT 2 (2017) } \\
\hline & & Aca 15 & $\begin{array}{c}\text { CO(On)5 } \\
\text { (Check) }\end{array}$ & Aca 15 & $\begin{array}{c}\text { CO }(\text { On)5 } \\
\text { (Check) }\end{array}$ & Aca 15 & $\begin{array}{c}\text { CO(On)5 } \\
\text { (Check) }\end{array}$ & Aca 15 & $\begin{array}{c}\text { CO(On)5 } \\
\text { (Check) }\end{array}$ \\
\hline 1. & HC \& RI, Periyakulam & 91.60 & 73.25 & 95.60 & 78.30 & 21.26 & 16.10 & 20.80 & 17.00 \\
\hline 2. & ARS, Bhavanisagar & 89.80 & 69.80 & 7.00 & 24.00 & 19.50 & 14.50 & 4.20 & 3.60 \\
\hline 3. & KVK, Sirugamani & 102.00 & 75.00 & -- & -- & 12.50 & 10.00 & -- & -- \\
\hline 4. & RRS, Paiyur & 53.50 & 44.50 & 135.60 & 123.40 & 3.10 & 2.08 & 14.46 & 9.72 \\
\hline 5. & TCRS, Yethapur & 89.40 & 77.60 & -- & -- & 22.60 & 17.10 & -- & -- \\
\hline 6. & KVK, Sandhiyur & 92.60 & 77.30 & -- & -- & 21.80 & 16.10 & -- & -- \\
\hline 7. & ARS, Vrinjipuram & 39.23 & 41.21 & -- & -- & 2.17 & 2.54 & -- & -- \\
\hline 8. & KVK, Vamban & -- & -- & 91.70 & 76.90 & -- & -- & 21.60 & 16.30 \\
\hline 9. & VRS, Palur & -- & -- & 91.60 & 78.50 & -- & -- & 20.00 & 17.00 \\
\hline 10. & AC \& RI, Killikulam & -- & -- & 89.85 & 78.81 & -- & -- & 20.15 & 15.14 \\
\hline & Mean & 79.73 & 65.52 & 85.23 & 76.65 & 14.70 & 11.20 & 16.87 & 13.13 \\
\hline
\end{tabular}

Table.3 District wise performance of aggregatum onion cultures in Adoptive Research Trials 2017-2018)

\begin{tabular}{|l|l|c|c|c|c|c|c|c|}
\hline $\begin{array}{c}\text { SI. } \\
\text { No. }\end{array}$ & \multicolumn{1}{|c|}{ Centre } & $\begin{array}{c}\text { No. of } \\
\text { trials }\end{array}$ & \multicolumn{2}{|c|}{ Average clump weight (g) } & \multicolumn{2}{|c|}{ Bulb yield/plot (Kg) } & \multicolumn{2}{|c|}{ Total bulb yield (t/ha) } \\
\hline & & Aca 15 & $\begin{array}{c}\text { CO(On)5 } \\
\text { (Check) }\end{array}$ & Aca 15 & $\begin{array}{c}\text { CO(On)5 } \\
\text { (Check) }\end{array}$ & Aca 15 & $\begin{array}{c}\text { CO(On)5 } \\
\text { (Check) }\end{array}$ \\
\hline 1 & Erode* & 10 & 122.10 & 90.00 & 37.54 & 29.15 & 15.04 & 11.66 \\
\hline 2 & Coimbatore & 8 & 91.16 & 72.47 & 9.32 & 7.12 & 20.65 & 16.00 \\
\hline 3 & Tiruppur & 8 & 91.25 & 74.36 & 9.36 & 7.67 & 20.97 & 16.12 \\
\hline 4 & Madurai & 2 & 84.66 & 71.46 & 7.50 & 5.71 & 20.30 & 15.80 \\
\hline 5 & Theni & 10 & 81.70 & 68.57 & 7.11 & 5.21 & 19.28 & 16.32 \\
\hline 6 & Cuddalore & 10 & 88.45 & 74.62 & 8.56 & 6.78 & 20.80 & 15.84 \\
\hline & Mean & $\mathbf{4 8}$ & $\mathbf{9 3 . 2 2}$ & $\mathbf{7 5 . 2 5}$ & $\mathbf{1 3 . 2 3}$ & $\mathbf{1 0 . 2 7}$ & $\mathbf{1 9 . 5 1}$ & $\mathbf{1 5 . 2 9}$ \\
\hline
\end{tabular}

* Plot size adopted is $5 \mathrm{~m}$ x $5 \mathrm{~m}$, all other districts $3 \mathrm{~m}$ x $2 \mathrm{~m}$ was followed

Table.4 Overall performance of aggregatum onion cultures for mean bulb yield per hectare (t)

\begin{tabular}{|l|c|c|c|}
\hline \multicolumn{1}{|c|}{ Particulars } & $\begin{array}{c}\text { No. of } \\
\text { trials }\end{array}$ & \multicolumn{2}{|c|}{$\begin{array}{c}\text { Mean bulb yield per hectare } \\
\text { (t) }\end{array}$} \\
\cline { 3 - 4 } & & Aca 15 & CO (On)5 (Check) \\
\hline HC \& RI, Coimbatore & 3 & 21.10 & $\mathbf{1 6 . 5 8}$ \\
\hline MLT & 13 & 15.79 & $\mathbf{1 2 . 1 6}$ \\
\hline ART & 48 & 19.51 & $\mathbf{1 5 . 4 0}$ \\
\hline OFT & 5 & 19.96 & $\mathbf{1 6 . 2 0}$ \\
\hline Overall Mean & 69 & $\mathbf{1 9 . 1 0}$ & 15.10 \\
\hline $\begin{array}{l}\text { Per cent increase over } \\
\text { CO(On) 5 (Check) }\end{array}$ & - & 20.94 & - \\
\hline
\end{tabular}


Table5 Quality parameters and organoleptic evaluation of aggregatum onion cultures

\begin{tabular}{|l|c|c|}
\hline \multicolumn{1}{|c|}{ Particulars } & Aca15 & $\mathrm{CO}(\mathrm{On}) 5$ \\
\hline Quality parameters & & \\
\hline TSS ${ }^{\circ}$ (Brix ) & 15.40 & $\mathbf{1 3 . 2 0}$ \\
\hline Ascorbic acid content $\mathbf{( m g / g )}$ & 10.80 & $\mathbf{8 . 0 7}$ \\
\hline Organoleptic evaluation* & & \\
\hline Colour & 9 & $\mathbf{7}$ \\
\hline Appearance & 8 & $\mathbf{7}$ \\
\hline Flavour & 9 & $\mathbf{8}$ \\
\hline Texture & 8 & $\mathbf{7}$ \\
\hline Taste & 8 & $\mathbf{7}$ \\
\hline * Based on nine point hedonic scale & & \\
\hline
\end{tabular}

Table.6 Artificial screening for Purple blotch disease (spore suspension method) and Thrips incidence

\begin{tabular}{|c|c|c|c|c|c|c|c|c|}
\hline \multirow{3}{*}{$\begin{array}{l}\text { SL. } \\
\text { No. }\end{array}$} & \multirow[t]{3}{*}{ Cultures } & \multirow{3}{*}{$\begin{array}{c}\text { No. of } \\
\text { plants } \\
\text { inoculated }\end{array}$} & \multicolumn{6}{|c|}{ No. of plants expressed symptoms } \\
\hline & & & \multicolumn{3}{|c|}{$\begin{array}{l}\text { Purple blotch disease by spore } \\
\text { suspension method }\end{array}$} & \multicolumn{3}{|c|}{ Thrips incidence } \\
\hline & & & 10 days & 20 days & 30 days & 10 days & 20 days & 30 days \\
\hline 1 & Aca15 & 10 & 5 & 5 & 5 & 6 & 6 & 6 \\
\hline 2 & $\mathrm{CO}(\mathrm{On}) 5$ (Check) & 10 & 5 & 6 & 6 & 7 & 7 & 7 \\
\hline
\end{tabular}

The organoleptic evaluation was done based on nine point hedonic scale. Based on the organoleptic test, Aca15 recorded maximum score 9 points for colour and flavour and 8 points appearance, texture and taste. However, the check variety $\mathrm{Co}(\mathrm{On}) 5$ recorded 7 points for colour, appearance, texture and taste. In onion, bulb colour is an important character because it decide the consumer preference. The difference in the bulb colour of variety is due to their genetic nature. These results were in conformity with the findings of Boukary et al. (2012) and Azoom et al. (2014). The bulbs of Aca15 are bolder in size, attractive pink in colour. Each clump has 5 - 7 bulblets. Dry pinkish scale leaves are arranged compactly on the bulbs and bulblets and moderately resistant to Purple Blotch and Thrips under field condition (Table.6).

The major reasons for the low productivity of onion are the paucity of varieties adapted to different agro-climatic situations and growing conditions and the incidence of pests and diseases. Among the pests, onion thrips is important and it is not only a damaging pest but also act as a vector for viral diseases. Based on the consistent performance for bulb yield, quality and seed setting type, Aca15 is released as CO 6 during 2019-20 for the benefit onion growing regions of Tamil Nadu.

\section{References}

Ahmed, A.A. and Bassuony, N.I.. 2009. Importance of medical herbs in animal feeding. World J.Agric.Sci., 5: 456-465.

Anbukkarasi,V., Paramaguru,P., Pugalendhi,L., Ragupathi,N., Jeyakumar, P.2013. Studies on pre and post-harvest treatments for extending shelf life in onion - A review. Agricultural Reviews. 34 (4):256-268.

Anbukkarasi,V., Paramaguru,P., Pugalendhi,L., Ragupathi,N., Jeyakumar, P.2012. Temperature treatments on postharvest handling of small onion (Allium cepa L. var. aggregatum Don.). Madras Agricultural Journal. 99(10/12): 673676.

Azoom, Kaouther Zhani, Cherif Hannachi., 2014. Performance of Eight Varieties of Onion (Allium cepa L.) Cultivated under Open Field in 
Tunisia. Notulae Scientific Biologicae, 6(2): 220-224

Boukary H, Haougui, A., Barage, M., Adam, T., Roumba, A., Saadou, M., 2012. Evaluation agro-morphology of onion varieties under ecotypes of Nigeria. Intl.J. Biological and Chemistry Science, 6(6): 3098-3106.

Brewster, J.L. 2008. Onions and other Vegetable Alliums. (2nd ed.), CAB International, North America.

Fathima, A, Paramaguru, P., Lakshmanan, V. and Venkatesan, K. 2019. Evaluation of aggregatum onion (Allium cepa var.aggregatum) genotypes for yield and quality traits. J.Agric. and Ecology.8:75-83.

Ijoyah, M.O, Rakotomavo, H., Naiken, M.V. 2008. Yield performance of four onions (Allium cepa L.) varieties compared with the local variety under open field conditions at Anse Boileau, Seychelles. J. Science and Technology, 28(3): 28-33.

Lanzotti, V.A.Romano,S. Lanzuise, G. Bonanomi and F.Scala, 2012. Antifungal saponins from bulbs of white onion Allium cepa L. Phytochemistry, 74: 133-139.

Mettananda, K.A., Fordham, R. 2001. The Effects of Plant Size and Leaf Number on the Bulbing of Tropical Short-day Onion Cultivars (Allium cepa L.) Under Controlled Environments. Journal of Horticultural Science, 14(5): 22-31.

Moulin, M.M., Rodrigues, R., Goncalves, Sudre, C.P., Dos Santo, Silva. 2012. Collection and morphological characterization of sweet potato landraces in North of Rio de Janeiro state. Horticultural Brassicae, 30(2): 286-292.

National Horticultural Board, 2019. Area and Production of Horticulture Crops - All India. New Delhi.

Panse, V.G. and Sukhatme, P.V. 1985. Statistical Methods for Agricultural Workers. Indian Council of Agricultural Research Publication. 87-89.

Pavlovic, N., Zecevic, B., Zdravkovic, M., Ivanovic, M., Damjanovic, M. 2003. Variability and heritability of average yield of onion bulb (Allium cepa L.). Genetics, 35(3): 149-154.

Pugalendhi,L. and Thangamani,C. 2011.Evaluation

\section{How to cite this article:}

Pugalendhi, L., K. Shoba Thingalmaniyan and Velmurugan, M. 2020. Evaluation of seed setting aggregatum onion (Allium cepa var. aggregatum) types under Tamil Nadu conditions. Int.J.Curr.Microbiol.App.Sci. 9(08): 3304-3310. doi: https://doi.org/10.20546/ijcmas.2020.908.378 of aggregatum onion (Allium cepa L. var. aggregatum Don.) genotypes. Allium and Umbelliferae Improvement Newsletter. 21: 1-5.

Pugalendhi,L., Sathiyamurty,V.A., Sumathi, T., Thangamani,C. 2011a. Weed management studies in onion. National Symposium on Alliums: Current Scenario and Emerging trends. 257.

Pugalendhi,L., Thangamani,C., Ragupathi,N. and Sumathi,T.2011b. Studies on integrated nutrient management in onion (Allium cepa L.). Allium and Umbelliferae Improvement Newsletter. 21: 45-48.

Savitha, B.K., Paramaguru,P. and Pugalendhi,L.2010. Effect of drip fertigation on growth and yield of onion. Indian Journal of Horticulture. 67 (4): 334-336.

Savitha, B.K., Paramaguru,P., and Pugalendhi, L.. 2012. Standardization of Fertigation in Onion (Allium Cepa L.). LAP Lambert Academic Publishing.

Savitha,B.K., Paramaguru,P., Usha Nandhini Devi,H. and Pugalendhi,L.2008. Effect of drip fertigation on yield and quality in big onion (Allium cepa var.cepa) and aggregatum onion (Allium cepa var.aggregatum). Allium and Umbelliferae Improvement Newsletter.18: 1020.

Shabina, S. Sharma,G. Irfan, M.A. 2020. A Review: Allium cepa aggregatum, characteristics, and properties. Gyanvihar. 6(1):1-6.

Sharma, S., Bal, S.S. and Bajaj, K.L. 1996. Chemical composition of some important varieties of onion (Allium cepa L.). Vegetable Science, 23(1): 48-51.

Shoba Thingalmaniyan, K., N. Rohini and Arumugam, T. 2017. Performance Evaluation of Aggregatum Onion Genotypes (Allium cepa Var. Aggregatum) for Yield, Quality and Resistance Characters. Int.J.Curr.Microbiol.App.Sci. 6(6): 634-642.

Veeraragavathatham, D., Pugalendhi, L., Amarnath, V. and Devi, H.U.N. 2006. Development of aggregatum onion variety $\mathrm{CO}(\mathrm{On}) 5$ at Tamil Nadu Agricultural University. Allium Improvement Newsletter. 16: 3-10. 